\title{
ВЛИЯНИЕ МИНЕРАЛЬНЫХ УДОБРЕНИЙ НА МИКРОФЛОРУ ПАХОТНОГО ЧЕРНОЗЕМА ЛЕСОСТЕПНОЙ ЗОНЫ ЗАУРАЛЬЯ
}

O.N. Demina, D.I. Eremin

\section{THE INFLUENCE OF MINERAL FERTILIZERS ON THE MICROFLORA OF ARABLE CHERNOZEM OF THE FOREST-STEPPE ZONE OF THE TRANS-URALS}

Демина Оксана Николаевна - асп. каф. почвоведения и агрохимии Государственного аграрного университета Северного Зауралья, г. Тюмень. E-mail: oksi.victorious@mail.ru

Еремин Дмитрий Иванович - д-р биол. наук, профр. каф. почвоведения и агрохимии Государственного аграрного университета Северного Зауралья, г. Тюмень. E-mail: soil-tyumen@yandex.ru

Сохранение почвенного плодородия в условиях интенсивного земледелия является весьма актуальным, а изучение факторов, влияющих на него, является теоретически и практически необходимым. Почвенная микрофрлора и микробиологические процессы играют особую роль в плодородии почвы. Цель исследований изучение изменения структуры почвенной микросрлоры при внесении возрастающих доз минеральных удобрений. Исследования проводили на стационаре кафедры почвоведения и агрохимии Государственного аграрного универсиmета Северного Зауралья, расположенного в северной лесостепи Зауралья. Численность эколого-троффических групп микроорганизмов определяли методом посева на питательные среды. Результаты исследований показали, что низкие дозы минеральных удобрений оказывают слабое влияние на развитие микробиоты. Систематическое внесение высоких доз удобрений существенно изменяло численность почвенной микрофллоры по фазам вегетации яровой пшеницы. Состав микроорганизмов на контроле и на варианте с внесением минеральных удобрений на планируемую урожайность $3,0 \mathrm{~m} / 2$ а зерна отличался незначительно и составлял 51,4-54,1 млн КОЕ/ г почвы. При внесении минеральных удобрений на планируемые урожайности 5,0 и 6,0 m/2а зерна численность микроорганизмов варьировала в
Demina Oksana Nikolayevna - Post-Graduate Student, Chair of Soil Science and Agrochemistry, State Agrarian University of Northern Trans-Urals, Tyumen.

E-mail: oksi.victorious@mail.ru

Eremin Dmitry Ivanovich - Dr. Biol. Sci., Prof. Chair of Soil Science and Agrochemistry, State Agrarian University of Northern Trans-Urals, Tyumen.

E-mail: soil-tyumen@yandex.ru

пределах 20-40 \% по отношению к контролю. Коэфффициент Мишустина на удобренных вариантах составил 1,2-1,4 ед., тогда как на контроле этот показатель составил 1,8 ед. Под действием высоких доз минеральных удобрений численность гумусообразующих микроорганизмов в весенний и осенний периоды достоверно возрастала. Коэфффициент олиготрофнности составил 0,8-0,5 и 1,0-0,7 ед. соответственно. Однако температурные условия в это время замедляют их деятельность. На варианте без внесения удобрений и на варианте с NPK на 3,0 m/га зерна в середине лета отмечены самые благоприятные условия для гумусоообразования. При достаточном количестве растительных остатков можно добиться положительного баланса гумуса. Коэфффициент олиготрофнности на этих вариантах составил 1,2-0,8 ed.

Ключевые слова: биологическая активность, почва, групповой состав микрофрлоры, аммонифрикаторы, олигонитрофилы, иммобилизаторы азота, коэфффициент олиготрофности, гумусовое состояние.

The preservation of soil fertility in the conditions of intensive agriculture is very relevant, and the study of factors affecting it is theoretically and practically necessary. Soil microflora and microbiological processes play a special role in soil fertility. The 
aim of the research was to study the changes in the structure of soil microflora when applying increasing doses of mineral fertilizers. The study was performed at land plot of the Department of Soil Science and Agrochemistry, State Agrarian University of Northern Trans-Urals, located in the Northern forest-steppe of Trans-Urals. The number of ecological and trophic groups of microorganisms was determined by seeding on nutrient media. The research results showed that low doses of mineral fertilizers had had a weak effect on the development of microbiota. Systematic application of high doses of fertilizers significantly changed the number of soil microflora in the phases of vegetation of spring wheat. The composition of microorganisms on the control and on the variant with the introduction of mineral fertilizers for planned yield of 3.0 t/hectares of grain did not differ significantly and amounted to 51.4-54.1 million colony forming units/g of the soil. When applying mineral fertilizers to planned yields of 5.0 and 6.0 t/hectare of grain, the number of microorganisms varied within $20-40 \%$ in relation to the control. Mishustin's coefficient on fertilized variants was 1.2-1.4 units, while on the control this indicator made 1.8 units. Under the influence of high doses of mineral fertilizers the number of humus-forming microorganisms in spring and autumn periods significantly increased. Oligotrophy coefficient made 0.8-0.5 units and 1.0-0.7 units, respectively. However, temperature conditions at this time slow down their activity. In the case of non-fertilization and in the case of NPK 3.0 thectare of grain in mid-summer the most favorable conditions for humus formation were noted. With sufficient amount of plant residues one can achieve positive humus balance. Oligotrophy coefficient of these options amounted to 1.2-0.8 units.

Keywords: biological activity, soil, group composition of microflora, ammonifiers, oligonitrophils, nitrogen immobilizers, oligotrophy coefficient, humus state.

Введение. Широкое применение минеральных удобрений - одно из необходимых условий интенсификации земледелия $[1,2]$. Эта объективная необходимость следует за ежегодным ростом численности населения и их потребности в продовольствии. Минеральные удобрения основной поставщик азота, фосфора и калия в пахотных почвах. Соответственно с помощью удобрений можно не только увеличить урожайность сельскохозяйственных культур, но и повысить продуктивность пашни в целом. Кроме того, правильно рассчитанные дозы минеральных удобрений будут как экономически эффрективными, так и экологически безопасными [3, 4]. Однако, оценивая положительное влияние минеральных удобрений на получение высоких урожаев сельскохозяйственных культур, не стоит забывать об их влиянии на биологические свойства вовлеченных в сельскохозяйственный оборот почв [5-7]. Нередко аграрии в погоне за высокими урожаями забывают, что минеральные удобрения являются мощным фрактором, оказывающим влияние на изменение состава почвенной микрофрлоры. Ученые микробиологи и почвоведы доказали изменение как количественного, так и качественного состава почвенной микрофрлоры при внесении минеральных туков $[8,9]$.

Почвенные микроорганизмы являются ключевым фактором почвообразования, и им принадлежит ведущая роль в процессах минерализации и гумификации почвенного органического вещества. Внесение умеренных доз минеральных удобрений способствует нарастанию бактериальной микрофрлоры, увеличивая тем самым скорость минерализующих процессов [10]. Грибная микрофлора и актиномицеты расщепляют сложные органические вещества и отзывчивы к высоким дозам минеральных удобрений [11]. Несмотря на то что изучением данного вопроса занимаются с 60-х годов прошлого столетия, однозначного ответа по влиянию минеральных удобрений на почвенную микрофрлору в условиях Северного Зауралья нет. Поэтому изучение микробных сообществ в пахотных почвах и влияние на них агрохимикатов актуально, практически значимо и важно для сельскохозяйственного производства. Следовательно, для одновременного увеличения урожайности сельскохозяйственных культур и сохранения почвенного плодородия необходимо использовать научно обоснованную систему удобрений и средств химизации, направленную на оптимизацию питания с учетом микробиологического состояния почв $[12,13]$.

Цель исследований. Изучить изменения количественного и качественного состава почвенной микрофлоры при внесении возрастающих доз минеральных удобрений в условиях северной лесостепи Зауралья. 
Объекты и методы исследований. Исследования по влиянию азотно-фосфрорных минеральных удобрений на микрофлору пахотного чернозема лесостепной зоны Зауралья проводили на стационаре кафедры почвоведения и агрохимии на опытном поле Государственного аграрного университета Северного Зауралья по следующей схеме: контроль (без удобрений); дозы удобрений $\mathrm{N}_{80} \mathrm{P}_{10} ; \mathrm{N}_{200} \mathrm{P}_{60} ; \mathrm{N}_{250} \mathrm{P}_{120}$ кг действующего вещества на гектар, что соответствовало уровню минерального питания, необходимого для формирования планируемой урожайности яровой пшеницы 3,0; 5,0 и 6,0 т/га зерна соответственно.

Стационар расположен на юге Тюменской области, в центральной части Тюменского района, что в 1,5 км от города Тюмени, вблизи д. Утешево.

Объектом исследований был чернозем выщелоченный, маломощный, тяжелосуглинистый. Морфологическое описание проводили по общепринятой методике. На стационарном опыте размещен трехпольный севооборот со следующим чередованием культур: однолетние травы, яровая пшеница, овес. Исследования проводили под пшеницей в трехкратной повторности.

Дозы внесенных минеральных удобрений рассчитывали методом элементарного баланса с учетом содержания питательных веществ в почве и текущей нитрификации - 80 кг/га $[1,14]$.

Образцы почвы на микробиологический анализ отбирали с пахотного горизонта 0-30 cм в течение вегетации, в основные фазы развития яровой пшеницы (посев, цветение, восковая спелость). Численность эколого-трофических групп микроорганизмов определяли в лаборатории экологии почв Агробиотехнологического центра ГАУ Северного Зауралья.

Количественный состав бактерий, минерализующих азот, и актиномицетов исследовали на крахмало-аммиачном агаре (КАА); аммонификаторов на мясо-пептонном агаре (МПА), нитрификаторов на голодном агаре (ГА). Для определе- ния влияния минеральных удобрений на структуру микробного сообщества дополнительно были рассчитаны следующие показатели:

- коэфффициент иммобилизации азота, отражающий соотношение бактерий, минерализующих азот, и бактерий-аммонисикаторов, $K_{\text {имм }}=[$ KАA $] /[\mathrm{MПA]}$;

- коэфффициент олиготрофнности - соотношение микроорганизмов, растущих на голодном

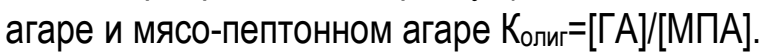

Результаты исследований и их обсуждение. Значительную долю в микробной биомассе пахотного чернозема лесостепной зоны Зауралья занимают аммонифицирующие и нитрифицирующие бактерии. Перед посевом яровой пшеницы численность аммонификаторов в слое 0-30 см на контроле составляла 6,1 млн КОЕ/г почвы (табл.). На варианте с внесением NP на планируемую урожайность 3,0 т/га зерна численность микроорганизмов этой же группы на $10 \%$ превышала контроль. Особое внимание необходимо уделить вариантам с высоким уровнем минерального питания. При систематическом внесении удобрений на планируемые урожайности 5,0 и 6,0 т/га зерна численность аммонификаторов была существенно выше контроля - 7,7 и 9,5 млн КОЕ. Это обусловлено последействием минеральных удобрений, вносимых в прошлые годы.

В фразу цветения численность аммонифицирующих бактерий на контроле была на $15 \%$ ниже, чем при посеве. Внесение минеральных удобрений на планируемую урожайность 3,0 т/га зерна оказало благоприятное воздействие на развитие данной группы микроорганизмов. Их численность превышала контроль почти на $30 \%$. При внесении возрастающих доз минеральных удобрений на планируемую урожайность зерна 5,0 и 6,0 т/га произошло резкое снижение их численности до 4,7 млн КОЕ/1 г почвы, что может быть связано с активным потреблением питательных веществ растениями яровой пшеницы. 
Вестник КрасТАУ. 2020. № 2

Влияние возрастающих доз минеральных удобрений на численность физиологических групп микроорганизмов, осуществляющих транссрормацию азота в почве, млн КОЕ/1 г почвы

\begin{tabular}{|c|c|c|c|c|c|c|c|c|c|}
\hline \multirow{2}{*}{ Вариант } & \multicolumn{3}{|c|}{$\begin{array}{c}\text { Аммонификаторы } \\
\text { (МПА) }\end{array}$} & \multicolumn{3}{|c|}{$\begin{array}{c}\text { Нитрификаторы } \\
\text { (олигонитрофилы) (ГА) }\end{array}$} & \multicolumn{3}{|c|}{$\begin{array}{c}\text { Иммобилизаторы азота } \\
(\text { КАА })\end{array}$} \\
\hline & $\begin{array}{l}\text { По- } \\
\text { сев }\end{array}$ & $\begin{array}{l}\text { Цве- } \\
\text { тение }\end{array}$ & $\begin{array}{l}\text { Убор- } \\
\text { ка }\end{array}$ & Посев & Чение & $\begin{array}{l}\text { Убор- } \\
\text { ка }\end{array}$ & Посев & $\begin{array}{l}\text { Цве- } \\
\text { тение }\end{array}$ & $\begin{array}{l}\text { Убор- } \\
\text { ка }\end{array}$ \\
\hline Контроль & 6,1 & 5,2 & 3,5 & 8,0 & 6,1 & 5,6 & 4,2 & 9,3 & 3,4 \\
\hline $\begin{array}{c}\text { NPK на 3,0 т/га } \\
\text { зерна }\end{array}$ & 6,7 & 7,3 & 3,7 & 8,0 & 6,2 & 5,5 & 4,2 & 8,9 & 3,6 \\
\hline $\begin{array}{c}\text { NPK на 5,0 т/га } \\
\text { зерна }\end{array}$ & 7,7 & 5,6 & 6,1 & 6,2 & 8,0 & 6,3 & 6,5 & 7,8 & 5,4 \\
\hline $\begin{array}{c}\text { NPK на 6,0 т/га } \\
\text { зерна }\end{array}$ & 9,5 & 4,7 & 10,7 & 5,0 & 7,6 & 7,7 & 6,1 & 5,6 & 5,1 \\
\hline
\end{tabular}

Перед уборкой яровой пшеницы численность аммонификаторов на варианте без внесения минеральных удобрений и на варианте с внесением удобрений на планируемую урожайность 3,0 т/га зерна была на одном уровне - 3,5-3,7 млн КОЕ/1 г почвы. Дальнейшее повышение уровня минерального питания стимулировало рост их численности. При внесении удобрений на планируемую урожайность 5,0 т/га микробная масса аммонифиицирующих бактерий превышала контроль почти в 2 раза и достигала 6,1 млн КОЕ/ г почвы. На варианте с максимальной насыщенностью минеральными удобрениями их численность составила 10,7 млн KOЕ/1 г почвы, что более чем в 3 раза превышало контроль.

Следующий за аммонификацией этап высвобождения азота путем разложения органических азотсодержащих соединений осуществляется нитрифицирующими бактериями. Численность олигонитрофилов перед посевом на контроле составила 8 млн КОЕ/1 г почвы. Внесение низких доз минеральных удобрений не оказало существенного влияния на их развитие. Повышение уровня минерального питания подавляло развитие нитрисикаторов, снижая их численность на 22,5 и 37,5\% соответственно относительно контроля. В фазу цветения отмечена обратная закономерность. Численность нитрифицирующих бактерий на контроле и варианте с внесением удобрений на планируемую урожайность зерна 3,0 т/га между собой отличалась незначительно. При внесении удобрений на планируемые урожайности 5,0 и 6,0 т/га зерна численность нитрификаторов увеличилась до 8 и 7,6 млн КОЕ/1 г почвы. К моменту созревания яровой пшеницы их количество вновь снижалось на контроле и на варианте с низким уровнем минерального питания, но увеличивалось на вариантах с максимальным насыщением минеральными удобрениями.

Иммобилизацию минерального азота осуществляют микроорганизмы, способные усваивать аммиачный, аммонийный и нитратный азот. От степени иммобилизации зависит содержание доступных форм азота в почве для растений. Численность бактерий - иммобилизаторов азота при посеве на контроле и на варианте с внесением минеральных удобрений на планируемую урожайность 3,0 т/га зерна была одинаковой и составила 4,2 млн КОЕ/1 г почвы. На вариантах с внесением минеральных удобрений на планируемую урожайность 5,0 и 6,0 т/га зерна отмечено увеличение численности иммобилизующих бактерий в среднем на 33,3 \%.

На контроле и варианте с внесением удобрений на планируемую урожайность 3,0 т/га в фазу цветения яровой пшеницы их количество было максимальным по сравнению с другими группами бактерий в этот же период. Их численность составила 9,3-8,9 млн КОЕ/1 г почвы соответственно. При внесении минеральных удобрений на планируемую урожайность 5,0 т/га зерна происходило снижение до 7,8 млн КОЕ/1 г почвы. На варианте с максимальным уровнем минерального питания отмечено угнетение иммобилизующих бактерий, численность которых была на 40 \% меньше контроля. Уменьшение количества иммобилизаторов азота в период 
цветения сохранялось до момента уборки, составляя 3,4-3,6 млн КОЕ/1 г почвы на контроле и на варианте с внесением NPK на 3,0 т/га зерна. На варианте с внесением NP на 5,0 т/га зерна отмечается увеличение этой группы микроорганизмов до 5,4 млн КОЕ/1 г почвы, что выше контроля на $37 \%$. Вариант с внесением NP на планируемую урожайность 6,0 т/га зерна отличается от предыдущего незначительно.

Влияние возрастающих доз минеральных удобрений на азотный режим почвы можно установить путем сопоставления коэффициента минерализации и иммобилизации Мишустина и коэффициента олиготрофности. Расчеты показали, что в весенний период коэфффициент минерализации в пахотном слое чернозема выщелоченного незначительно варьировал от 0,6 до 0,8 ед. (рис.1). Это указывает на процесс микробиологического поглощения минерального азота, что приводит к ухудшению азотного режима пахотных почв и является теоретическим обоснованием необходимости использования азотных удобрений в весенний период в условиях Северного Зауралья [15, 16].

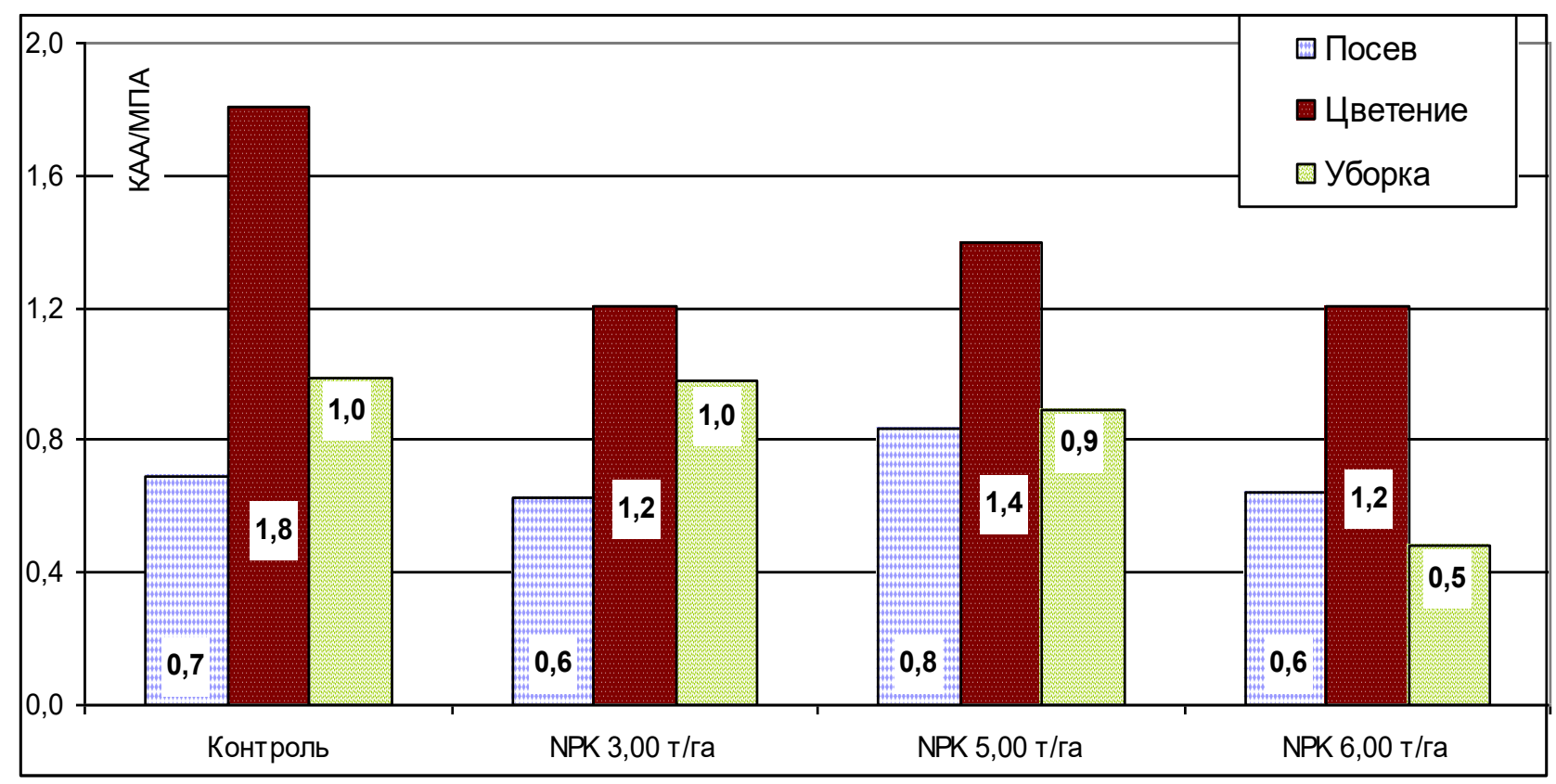

Puc. 1. Динамика коэффрициента минерализации и иммобилизации Мишустина (КАA/МПА) при внесении минеральных удобрений, ед.

В период цветения на контроле коэффрициент Мишустина увеличился до максимальных значений - 1,8 ед., что указывает на интенсивную минерализацию органического вещества почвы и высвобождение из него азота. При внесении минеральных удобрений коэфффициент уменьшился до 1,2-1,4 ед., что на 22-33 \% ниже значений контроля. Данный факт указывает на негативное воздействие минеральных удобрений на развитие бактерий и актиномицетов, минерализующих азот.

Перед уборкой урожая коэффрициент мобилизации на контроле и на варианте с внесением минеральных удобрений на планируемые урожайности 3,0 и 5,0 т/га зерна был одинаковым и составил 0,9-1,0 ед., что в свою очередь свидетельствует о сбалансированности процессов минерализации и иммобилизации азота в пахотном черноземе. На варианте с максимальным уровнем минерального питания (NP на 6,0 т/га зерна) коэффрициент Мишустина достиг минимальных величин - 0,5 ед., что указывает на поглощение минерального азота удобрений почвенной микрофлорой. Для Северного Зауралья это является положительным моментом, поскольку существенно уменьшается вероятность вымывания неизрасходованного минерального азота в осенний и весенний периоды.

Наиболее интересным показателем, сочетающим в себе активность микрофолоры и 
трансформацию почвенного органического вещества, является отношение численности микроорганизмов, развивающихся на голодном и мясо-пептонном агаре, выражаемое коэфффициентом олиготрофности. Наши расчеты показали, что в весенний период микрофрлора активно разрушает почвенные органические вещества на вариантах с невысокими дозами минеральных удобрений (контроль, NP на 3,0 т/га). Коэфффициент олиготрофности на них составил 1,3 и 1,2 ед. соответственно (рис. 2). На участках, где систематически вносили высокие дозы удобрений (NP на 4,0 и 5,0 т/га), этот показатель был существенно ниже и достигал 0,8 и 0,5 ед. соответственно. Это указывает на потенциальное гумусообразование пахотного слоя чернозема при использовании высоких доз минеральных удобрений. Однако нужно учитывать, что при дефиците растительных остатков положительный баланс гумуса не будет достигнут.

К моменту цветения, которое приходится на первую половину июля, коэфффициент олиготрофрности на контроле остается на прежнем уровне - 1,2 ед. относительно весеннего периода. Это свидетельствует о том, что процесс ми- нерализации органического вещества преобладает над гумусообразованием в пахотном черноземе при отсутствии минеральных удобрений. В конце вегетации минерализация существенно возрастает, о чем свидетельствует повышение коэффициента до максимальных величин (1,6 ед.).

На варианте с внесением удобрений на планируемую урожайность 3,0 т/га зерна отношение микроорганизмов, растущих на голодном и мясопептонном агаре, в середине лета уменьшилось до 0,8 ед., что указывает на благоприятные условия для гумусообразования. При наличии достаточного количества растительных остатков можно добиться положительного баланса гумуса при систематическом внесении минеральных удобрений. К уборке на варианте с NP на 3,0 т/га азотный режим ухудшается, что приводит к резкому росту численности нитрификаторов, указывая на создание условий для активной минерализации почвенного органического вещества. Нужно отметить, что этот период достаточно короткий, поскольку почва быстро охлаждается в сентябре-октябре, тем самым существенно снижая ее биологическую активность.

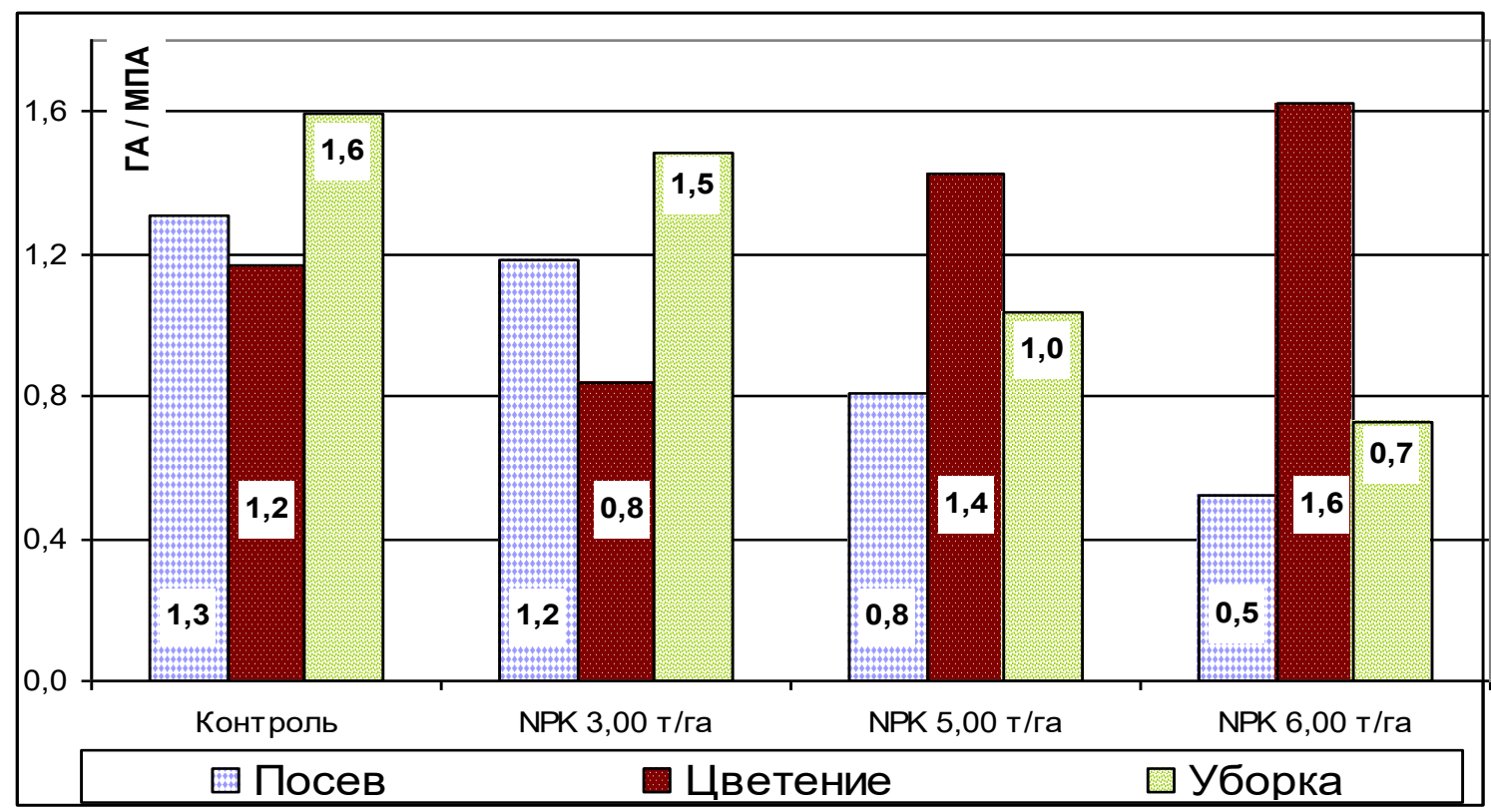

Puс. 2. Коэффрициент олиготрофности пахотного чернозема при внесении возрастающих доз минеральных удобрений, ед.

Систематическое внесение высоких доз минеральных удобрений под зерновые культуры (NP на 5,0 и 6,0 т/га) привело к резкому повышению коэффициента олиготрофоности до 1,4 и
1,6 ед. соответственно. Данное обстоятельство указывает на сильную минерализацию органического вещества в середине лета. Это также подтверждается исследованиями А.А. Ахтямо- 
вой, которая изучала скорость разложения соломы на этих же агрофонах [17]. В конце вегетации зерновых культур коэфффициент олиготрофноости снизился до 1,0 и 0,7 ед. соответственно. Это произошло за счет увеличения численности аммонификаторов (МПА) во второй половине лета, что компенсировало активность олигонитрофилов (ГА), разрушающих органическое вещество.

Заключение. Внесение минеральных удобрений в дозе на планируемую урожайность 3,0 т/га зерна яровой пшеницы оказывает благотворное влияние на численность аммонификаторов в пахотном черноземе, которая возросла на 30 \% относительно контроля. Использование более высоких доз минеральных удобрений угнетает микроорганизмы данной группы в первой половине вегетации яровой пшеницы. К уборке численность аммонификкаторов на вариантах с высоким уровнем минерального питания возрастает относительно контроля до 6,1-10,7 млн КОЕ/1 г почвы. Это в 2-3 раза выше контроля. Высокие дозы удобрений не оказали достоверного влияния на количество нитрификаторов. Коэфффициент минерализации и иммобилизации в весенний период в пахотном черноземе составил 0,6-0,8 ед., что обусловлено низкой температурой почвы в этот период. В течение вегетации на контроле коэффициент Мишустина был максимальным - 1,8 ед. Внесение удобрений оказало благоприятное действие на процесс минерализации и иммобилизации азота в почве. На удобренных вариантах усиливается процесс иммобилизации азота, тем самым предотвращая его вымывание в осенневесенний период.

Внесение невысоких доз минеральных удобрений весной не повлияло на развитие нитрифицирующих бактерий, их численность была на уровне с контролем. В период вегетации яровой пшеницы высокие дозы минеральных удобрений (NPK на 5,0 и 6,0 т/га зерна) существенно усилили процесс минерализации почвенного органического вещества относительно гумусообразования, о чем свидетельствует варьирование коэфффициента олиготрофрности с 0,5-0,8 до 1,2-1,6 ед. В послеуборочный период данный коэфффициент снизился до первоначальных значений. Однако в условиях Западной Сибири это не может оказать положительного влияния на гумусообразование вследствие охлаждения почвы.

\section{Литература}

1. Шерстобитов С.В. Диффференцированное внесение азотных удобрений с использованием систем спутниковой навигации: автореф. дис. .... канд. С.-х. наук. - М., 2015. - 22 с.

2. Еремин Д.И. Продуктивность зернового с занятым паром севооборота в условиях Северного Зауралья: дис. ... канд. с.-х. наук. - Тюмень, 2002. - 205 с.

3. Логинов Ю.П., Казак А.А. Пластичность и стабильность сортов картофеля в лесостепи Тюменской области // Известия Оренбургского государственного аграрного университета. - 2017. - № 5 (67). - C. 73-77.

4. Fomina M.N. New Generation Varieties of Spring Oats Selected for Areas with the Climate as in Ural, Siberia and the Far East of Russia // International scientific and practical conference "AgroSMART -Smart solutions for agriculture" (Agro-SMART, 2018). - 2018. P. 201-205.

5. Еремина Д.В. Математическая модель минерального питания яровой пшеницы по результатам многолетних исследований Государственного аграрного университета Северного Зауралья // Вестник КрасГАУ. 2017. - № 1 (124). - C. 14-19.

6. Миллер Е.И., Рзаева В.В., Миллер С.С. Применение органических удобрений на фоне основной обработки почвы при возделывании кукурузы на силос в Западной Сибири // Вестник Мичуринского государственного аграрного университета. - 2019. № 1. - C. 60-63.

7. Моторин А.С., Иәловиков А.В. Динамика различных форм азота при проведении биологической рекультивации нарушенных земель в условиях Крайнего Севера // Агропродовольственная политика России. 2017. - № 12 (72). - С. 88-92.

8. Перфильев Н.В., Вьюшина О.А., Майсямова Д.Р. Системы основной обработки и формирование ассоциаций микроорганизмов в темно-серой лесной почве // Достижения науки и техники АПК. - 2015. - Т. 29. - № 10. C. 16-17.

9. Чупрова В.В., Ерохина Н.Л., Александрова С.В. Запасы и потоки азота в агроценозах Средней Сибири. - Красноярск, 2006. - 171 с.

10. Еремин Д.И., Попова О.Н. Влияние минеральных удобрений на интенсивность разложения целлюлозы в пахотном черноземе 
лесостепной зоны Зауралья // Вестник ГАУ Северного Зауралья. - 2016. - № 4 (35). C. 27-33.

11. Майсямова Д.Р. Биологический режим темно-серых лесных почв в процессе сельскохозяйственного использования // Сибирский вестник сельскохозяйственной науки. 2005. - № 5. - С. 17-23.

12. Ульянова О.А., Кураченко Н.Л., Чупрова В.В. Влияние системы удобрения на плодородие чернозема выщелоченного Красноярской лесостепи // Агрохимия. - 2010. - № 1. C. 10-19.

13. Еремин Д.И., Демин Е.А. Агроэкологическое обоснование выращивания кукурузы на зерно в условиях лесостепной зоны Зауралья // Вестник ГАУ Северного Зауралья. 2016. - № 1 (32). - C. 6-11.

14. Котченко С.Г., Груздева Н.А., Еремин Д.И. Динамика содержания различных форм азота в пахотных серых лесных почвах Северного Зауралья // Плодородие. - 2017. № 4. - C. 39-43.

15. Демин Е.А., Фисунов Н.В. Влияние минеральных удобрений и междурядной обработки на урожайность кукурузы в условиях лесостепной зоны Зауралья // Вестник Курганской ГСХА. - 2017. - № 4 (24). - С. 33-35.

16. Синявский И.В., Чиняева Ю.З., Калганов А.А. Агроэкологическая и микробиологическая оценка последействия органо-минеральных удобрений, полученных на основе птичьего помета // АПК России. - 2017. - Т. 24. - № 5. - C. 1134-1140.

17. Ахтямова А.А. Роль запахиваемой соломы в стабилизации гумусового состояния пахотных черноземов // Известия Оренбургского государственного аграрного университета. - 2018. - № 3 (71). - С. 23-24.

\section{Literatura}

1. Sherstobitov S.V. Differencirovannoe vnesenie azotnyh udobrenij $\mathrm{s}$ ispol'zovaniem sistem sputnikovoj navigacii: avtoref. dis. ... kand. s.-h. nauk. - M., 2015. - $22 \mathrm{~s}$.

2. Eremin D.I. Produktivnost' zernovogo s zanyatym parom sevooborota $v$ usloviyah Severnogo Zaural'ya: dis. ... kand. s.-h. nauk. Tyumen', 2002. - $205 \mathrm{~s}$.

3. Loginov Yu.P., Kazak A.A. Plastichnost' i stabil'nost' sortov kartofelya $v$ lesostepi
Tyumenskoj oblasti // Izvestiya Orenburgskogo gosudarstvennogo agrarnogo universiteta. 2017. - № 5 (67). - S. 73-77.

4. Fomina M.N. New Generation Varieties of Spring Oats Selected for Areas with the Climate as in Ural, Siberia and the Far East of Russia // International scientific and practical conference "AgroSMART -Smart solutions for agriculture" (Agro-SMART, 2018). - 2018. S. 201-205.

5. Eremina D.V. Matematicheskaya model' mineral'nogo pitaniya yarovoj pshenicy po rezul'tatam mnogoletnih issledovanij Gosudarstvennogo agrarnogo universiteta Severnogo Zaural'ya // Vestnik KrasGAU. - 2017. - № 1 (124). - S. 14-19.

6. Miller E.I., Rzaeva V.V., Miller S.S. Primenenie organicheskih udobrenij na fone osnovnoj obrabotki pochvy pri vozdelyvanii kukuruzy na silos v Zapadnoj Sibiri // Vestnik Michurinskogo gosudarstvennogo agrarnogo universiteta. - 2019. - № 1. - S. 60-63.

7. Motorin A.S., Iglovikov A.V. Dinamika razlichnyh form azota pri provedenii biologicheskoj rekul'tivacii narushennyh zemel' v usloviyah Krajnego Severa // Agroprodovol'stvennaya politika Rossii. - 2017. - № 12 (72). - S. 88-92.

8. Perfil'ev N.V., V'yushina O.A., Majsyamova D.R. Sistemy osnovnoj obrabotki i formirovanie associacij mikroorganizmov v temno-seroj lesnoj pochve // Dostizheniya nauki i tekhniki APK. 2015. - T. 29. - № 10. - S. 16-17.

9. Chuprova V.V., Erohina N.L., Aleksandrova S.V. Zapasy i potoki azota $v$ agrocenozah Srednej Sibiri. - Krasnoyarsk, 2006. - $171 \mathrm{~s}$.

10. Eremin D.I., Popova O.N. Vliyanie mineral'nyh udobrenij na intensivnost' razlozheniya cellyulozy $v$ pahotnom chernozeme lesostepnoj zony Zaural'ya // Vestnik GAU Severnogo Zaural'ya. - 2016. - № 4 (35). - S. 27-33.

11. Majsyamova D.R. Biologicheskij rezhim temno-seryh lesnyh pochv $v$ processe sel'skohozyajstvennogo ispol'zovaniya // Sibirskij vestnik sel'skohozyajstvennoj nauki. 2005. - № 5. - S. 17-23.

12. Ul'yanova O.A., Kurachenko N.L., Chuprova V.V. Vliyanie sistemy udobreniya na plodorodie chernozema vyshchelochennogo Krasnoyarskoj lesostepi // Agrohimiya. - 2010. - № 1. - S. 10-19. 
13. Eremin D.I., Demin E.A. Agroekologicheskoe obosnovanie vyrashchivaniya kukuruzy na zerno v usloviyah lesostepnoj zony Zaural'ya // Vestnik GAU Severnogo Zaural'ya. - 2016. № 1 (32). - S. 6-11.

14. Kotchenko S.G., Gruzdeva N.A., Eremin D.I. Dinamika soderzhaniya razlichnyh form azota $v$ pahotnyh seryh lesnyh pochvah Severnogo Zaural'ya // Plodorodie. - 2017. - № 4. S. 39-43.

15. Demin E.A., Fisunov N.V. Vliyanie mineral'nyh udobrenij i mezhduryadnoj obrabotki na urozhajnost' kukuruzy $v$ usloviyah lesostepnoj zony Zaural'ya // Vestnik Kurganskoj GSKHA. - 2017. - № 4 (24). - S. 33-35.

16. Sinyavskij I.V., Chinyaeva Yu.Z., Kalganov A.A. Agroekologicheskaya i mikrobiologicheskaya ocenka posledejstviya organo-mineral'nyh udobrenij, poluchennyh na osnove ptich'ego pometa // APK Rossii. - 2017. - T. 24. - № 5. S. 1134-1140.

17. Ahtyamova A.A. Rol' zapahivaemoj solomy v stabilizacii gumusovogo sostoyaniya pahotnyh chernozemov // Izvestiya Orenburgskogo gosudarstvennogo agrarnogo universiteta. 2018. - № 3 (71). - S. 23-24. 